\title{
Onikişubat (Kahramanmaraş) yöresinde gıda olarak tüketilen bazı doğal bitki taksonlarına ait yöresel tarifler
}

\author{
Ebru Hatice Tığlı Kaytanlığlua,* (D), Hüseyin Fakira (i), Aslı Nisa Aydemir ${ }^{a}$ (iD)
}

\begin{abstract}
Özet: Onikişubat yöresinde (Kahramanmaraş) doğal olarak yetişen ve gida olarak tüketilen bazı doğal bitki taksonlarına ait yöresel tarifleri tespit etmek amacıyla yapılmıştır. Çalışmada veri toplama aracı olarak 10 soruluk anket formu kullanılmıştır. Anket uygulaması kırsal kesimde yaşayan 101 kişiyle yapılmıştır. Anket sonucunda 9 bitki taksonu belirlenmiştir. Belirlenen bitkiler 2019 yılı vejetasyon döneminde toplanmıştır. Çalışma sonucunda yemek yapımında kullanılan bitkiler; 1şgın (Pistacia terebinthus L. subsp. palaestina (Boiss.) Engler), tırşik (Arum maculatum L.), yarpuz (Mentha pulegium L.), ebegümeci (Malva sylvestris L.), gelinali (Papaver rhoeas L.), semizotu (Portulaca oleracea L.), su teresi, 1spatan (Nasturtium officinale R.Br.), ısırgan (Urtica dioica L.), çiriş (Asphodelus aestivus Brot.)'dir. Bu doğal bitkiler, sağlıklı ve doğal beslenmenin yanı sıra yöre halkı tarafından ekonomik kazançta sağlamaktadır. Onikişubat yöresinde doğal olarak yetişen bitkilerin gıda olarak tüketilmesi ve gelecek nesillere bu bilgilerin aktarılması amacıyla bu bitkilerle yapılan yöresel tariflere yer verilmiştir. Pistacia terebinthus'tan yapılan dürüm ve Mentha pulegium'dan yapılan çorba literatüre kazandırılmıştır.

Anahtar kelimeler: Yenilebilir otlar, Yöresel tarif, Kahramanmaras
\end{abstract}

\section{Local recipes of some natural plant taxon consumed as food in Onikişubat (Kahramanmaraş) region}

\begin{abstract}
In this study was made to determine the local recipes of some natural plant taxa that grow naturally in the Onikisubat region (Kahramanmaraş) and are consumed as food. A questionnaire with 10 questions was used as a data collection tool in the study. The survey application was made with 101 people living in rural areas. As a result of the survey, 9 plant taxa were determined. The determined plants were collected in the 2019 vegetation period. As a result of the study, the plants used in cooking; 1sgın (Pistacia terebinthus L. subsp. palaestina (Boiss.) Engler), tırsik (Arum maculatum L.), yarpuz (Mentha pulegium L.), ebegümeci (Malva sylvestris L.),gelinali (Papaver rhoeas L.),semizotu ( Portulaca oleracea L.), su teresi, 1spatan (Nasturtium officinale R.Br.), isırgan (Urtica dioica L.), ciris (Asphodelus aestivus Brot.). These natural plants, in addition to healthy and natural nutrition, provide economic gain by the local people. In order to consume the naturally grown plants in the Onikisubat region as food and to transfer this information to future generations, local recipes made with these plants are included. The wrap made from Pistacia terebinthus and the soup made from Mentha pulegium have been brought to the literature.

Keywords: Wild edible plants, Local recipe, Kahramanmaraş
\end{abstract}

\section{Giriş}

Ot kelimesi insanlar tarafindan yetiştirilmesinden ziyade doğal ortamda kendiliğinden yetişen bitkiler olarak tanımlanmakta olup, yabani veya yabanc1 otlar diye de adlandırılmaktadır (Karaca vd., 2015). Yenilebilir ot ise; belirli bir büyümeye gelmiş ve uygun şekillerde birkaç parçası yenmek için toplanan ve mutfaklarda kullanılan çoğunluğu yabani bitki olan türlerdir. Bunun yanı sıra bu bitkiler kırsal bölgelerde kendiliğince yetişen veya tarımı yapılan bitkilerdir (Kallas, 1996).

Yöre insanları tarafindan belirli mevsimlerde toplanan bu otlar, o yörenin insanlarına hem besin maddesi olarak, hem de yöre pazarlarında satılarak kazanç sağlamaktadır. Yapılan bazı çalışmalara göre bu otların sağlıklı beslenme de önemli bir değere sahip olduğu ve hastalıkları geciktirmede önemli bir potansiyele sahip olduğu düşünülmektedir (Knight, 2000). Yenilebilir otlardan sarmalar, sebzeli yemekler, çorbalar, börekler, tatlllar yapılmaktadır. Ayrıca bu otlar, taze ve kurutularak baharat ve çay olarak da kullanılmaktadır.

Doğu Akdeniz'de bulunan Kahramanmaraş, Başkonuş ve Yavşan yaylaları, Kapıçam Tabiat Parkı, Körçoban Tabiatı Koruma Alanı, mağaraları, barajları, akarsuları, gölleri, dağları, Germanicia Mozaikleri, Eshab-1 Kehf Külliyesi, kaleleri, tarihi camileri ve çarşıları, geleneksel el sanatları, yöresel mutfağ 1 ve coğrafi işaret olarak da tescil edilmiş olan tarhanası, pul biberi, dondurması gibi değerleri ile önemli paya sahiptir. Akdeniz iklim kuşağında olmakla birlikte Orta ve Doğu Anadolu iklim kuşakları ile birlikte sınır teşkil etmektedir (KTB, 2020).

Türk mutfağının en sevilen geleneksel yemeklerine ev sahipliği yapan Kahramanmaraş'ın yöresel yemeklerinden olan Acem Pilavı havuç, et, fistık, bol baharat, kuş üzümü ve ek olarak çeşitli sebzeler katılarak yapılan doyurucu bir pilavdır. Tırşik çorbası, pancar çeşitlerinden olan tırşik

\footnotetext{
$\triangle$ a Isparta Uygulamalı Bilimler Üniversitesi, Orman Fakültesi, Isparta

@ * Corresponding author (İletişim yazarı): ebrukaytanlioglu@ isparta.edu.tr

$\checkmark \quad$ Received (Geliş tarihi): 05.02.2021, Accepted (Kabul tarihi): 09.03.2021
}

Citation (Atıf): Tığlı Kaytanlığlu, E.H., Fakir, H., Aydemir, A.N., 2021. Onikişubat (Kahramanmaraş) yöresinde gida olarak tüketilen bazı doğal bitki taksonlarına ait yöresel tarifler. Turkish Journal of Forestry, 22(1): 83-90. DOI: $10.18182 /$ tjf.875214 
toplanıp temizlenir ve ayran ile servis edilerek tüketime hazırlanır. Boranı çorbası, yabani otlar, bulgur ve mercimek ile haşlanır. Haşlanan bu karışıma yoğurt eklenerek soğuk bir çorba elde edilir (YG, 2020).

Çalışmada Onikişubat yöresinde (Kahramanmaraş) yaşayan halkın kullandığı doğal (yabani) bitkilerin bilimsel, yöresel adları ve yöre halkının yemek yapımında kullandığ doğal bitkilerin kullanım şekillerini kayıt altına almak amaçlanmıştır. Bu yöresel tariflerin bölge turizm çekiciliği açısından ve Akdeniz bölgesi ve Türk mutfağına değer katabileceği düşünülmekte olup bu alanda yapılan çalışmalara da katkı sağlayabilecektir.

\section{Materyal ve yöntem}

Çalışma materyalleri, Onikişubat (Kahramanmaraş) yöresinden "37.582281" enlem, "36.926121" boylam arasından temin edilmiştir (Şekil 1). Materyaller 2020 yılı vejetasyon dönemi içerisinde yapılan arazi çalışmaları ile toplanmıştır (Şekil 2).

Bitki örnekleri budama makası ve bıçak yardımı ile kesilmiş ve kâğıt ambalajlara koyulmuştur. Bitkilerin bir kısmı yemek yapımı için ayrılmış bir kısmı da mevki, yükselti, toplanma zamanı, toplayan kişinin bilgileri kayıt edilerek, herbaryum örneği haline getirilmiştir. Herbaryum örneği haline getirilen bitkiler Isparta Uygulamalı Bilimler Üniversitesi, Orman Fakültesi Herbaryumu'nda muhafaza altına alınmıştır. Bitkileri teşhis etmek için Davis (1985) kaynaktan yararlanılmıştır.

Onikişubat (Kahramanmaraş) Yöresinde doğal bitkilerin tüketimi bir kültür haline gelmiş ve yöresel tarifler günümüze kadar gelmiştir. Bu amaçla yörede kullanılan bitkiler, temin biçimleri, kullanılan kısımları ve yemek yapımında kullanımı ile ilgili bilgi kaynakları ve tarifler hakkındaki bilgileri belirlemek için anket çalışmaları yürütülmüştür. Örnek büyüklüklerinin belirlenmesinde sinırlı toplumlarda kullanılan ve aşağıda açıklanan eşitlikten (1) faydalanılmıştır (Baş, 2010);

$$
n=\frac{N t^{2} p q}{d^{2}(N-1)+t^{2} p q}
$$

Burada;

n : Örnek büyüklüğünü,

$\mathrm{t}$ : Belirli bir anlamlılık düzeyinde $\mathrm{t}$ tablosuna göre bulunan teorik değer (\%95 güven düzeyi için 1,96),

$\mathrm{N}$ : Ana kütle büyüklüğünü,

$\mathrm{p}$ : Ölçmek istenilen büyüklüğün ana kütlede bulunma olasılığını $(0,5)$,

q : Ölçmek istenilen büyüklügün ana kütlede bulunmama olasılı̆̆ını $(0,5)$,

d : Kabul edilen örnekleme hatasını (Bu çalışmada \%10 olarak alınmıştır) göstermektedir.

(1) nolu eşitliğe göre hesaplanan örnek büyüklüğü asgari 96 kişi olarak belirlenmiş olup, 101 kişi ile yüzyüze anket yapılmıştır. Anket çalışmaları kapsamında yöresel yemeklerin yapımını sürdüren ve kırsal kesimde yaşayan orta yaşlı, yaşlı ve ev hanımı kadınlar ağırlıklı olarak seçilmiştir. Anket verilerinin değerlendirilmesi için yüzde oranlar kullanılmıştır. Tariflere ilişkin elde edilen bilgiler ise derlenerek sunulmuştur.

\section{Bulgular}

\subsection{Katılımcıların sosyo-demografik özellikleri}

Onikişubat (Kahramanmaraş) yöresinde yapılan anket çalışmalarına katılan tüketicilerin \%29,7'unu erkekler, \%70,3 'ini kadınlar oluşturmaktadır. Ankete katılan katılımcılar arasında 18-25 yaş grubu (\%15,8), 26-45 yaş grubu $(\% 38,6), 46-65$ yaş grubu $(\% 40,6), 66$ ve üzeri yaş grubu $(\% 5,0)$ ağırlıktadır. 46-65 yaş grubu ile birlikte değerlendirildiğinde $(\% 40,6)$, ankete katılanların büyük bir bölümünün orta yaş grubunda olduğu görülmektedir. Katılımcılar arasında evli grup daha ağır basmaktadır. Katılımcıların büyük bölümü lise mezunu kişilerden oluşmaktadır. Katılımcıların büyük bir bölümü düşük (01000 TL: \%45,5) gelir düzeyindedir (Çizelge 1).

\subsection{Yörede yemek yapımında kullanılan bitkiler, temin biçimleri ve kullanılan kısımları}

Yapılan çalışma sonucunda 9 bitki taksonuna ait familya adı, bilimsel adı, yöresel adı, gıda olarak tüketilen kısımları Çizelge 2'de gösterilmiştir.

Katılımcıların \%86,4'ünün yemek yapımı için bitkileri köy pazarından temin ettiği, \%96,6'sının sürgün kısımlarını çoğunlukla kullandığı, \%98,3'ünün yöresel bitkilerden yemek yapımı ile ilgili bilgileri aile büyüklerinden öğrendiği belirlenmiştir. Yöresel yemeklerin çoğunlukla ayda en az bir kez yapıldığ 1 görülmektedir. (Çizelge 3 ).

Çizelge 1. Katılımcıların sosyo-demografik özellikleri

\begin{tabular}{lc}
\hline Cinsiyet & $\%$ \\
\hline Kadın & 70,3 \\
Erkek & 29,7 \\
\hline Medeni durum & $\%$ \\
\hline Bekar & 23,8 \\
Evli & 76,2 \\
\hline Yaş & $\%$ \\
\hline $18-25$ & 15,8 \\
$26-45$ & 38,6 \\
$46-65$ & 40,6 \\
66 ve üzeri & 5,0 \\
\hline Eğitim & $\%$ \\
\hline Okur yazar olmayan & 3,0 \\
İlkokul & 13,9 \\
Ortaokul & 15,8 \\
Lise & 41,6 \\
Üniversite & 25,7 \\
\hline Aylik Gelir (TL) & $\%$ \\
\hline 0-1000 & 45,5 \\
1001-3000 & 6,9 \\
3000-5000 & 18,8 \\
5001 ve üzeri & 28,8 \\
\hline
\end{tabular}


Çizelge 2. Onikişubat (Kahramanmaraş) yöresinde bazı gıda olarak tüketilen doğal bitki taksonlarına ait bilgiler

\begin{tabular}{|c|c|c|c|c|c|c|}
\hline Familya adı & Latince tür adı & Yöresel adı & Gıda olarak tüketilen kısmı & Mevki & Yükselti & $\begin{array}{l}\text { Toplanma } \\
\text { zamanı }\end{array}$ \\
\hline Anacardiaceae & $\begin{array}{l}\text { Pistacia terebinthus L.subsp. } \\
\text { palaestina (Boiss.) Engler }\end{array}$ & Işgin & Taze yaprak ve sürgün & Şerefoğlu köyü & $576 \mathrm{~m}$ & Nisan \\
\hline Araceae & Arum maculatum L. & Tirşik & Yaprak ve sap kısımları & Ahır dağ1 & $1243 \mathrm{~m}$ & Nisan \\
\hline Lamiaceae & Mentha pulegium L. & Yarpuz & Yaprak & Çakallı köyü & & Nisan \\
\hline Malvaceae & Malva sylvestris $\mathrm{L}$. & Ebegümeci & Yaprak & Şerefoğlu köyü & $624 \mathrm{~m}$ & Nisan \\
\hline Papaveraceae & Papaver rhoeas $\mathrm{L}$. & Gelinali & Taze yaprak & Şerefoğlu köyü & $546 \mathrm{~m}$ & Nisan \\
\hline Portulacaceae & Portulaca olerace L. & Semizotu & Yaprak & Ahır dağ1 & $1145 \mathrm{~m}$ & Mayıs \\
\hline Urticaceae & Nasturtium officinale $\mathrm{R} . \mathrm{Br}$. & Ispatan & Yaprak & Çakallı köyü & $486 \mathrm{~m}$ & Nisan \\
\hline Urticaceae & Urtica dioica $\mathrm{L}$. & Isirgan & Yaprak & Şerefoğlu köyü & $675 \mathrm{~m}$ & Mayıs \\
\hline Xanthorrhoeaceae & Asphodelus aestivus Brot. & Çiriş & Yaprak ve sap kısımları & Şerefoğlu köyü & $736 \mathrm{~m}$ & May1s \\
\hline
\end{tabular}

\subsection{Yöresel tarifler}

\subsubsection{Işgin Böreği (Pistacia terebinthus L.subsp. palaestina)}

Işgın yaprakları araziden toplanır. Yemek hazırlı̆̆ı için yaprakları saplarından ayrılır. Ayrılan yapraklar sirkeli suda yıkanarak temizlenir. Yapraklar kaynamış suyun içine atılarak 10 dakika kaynatılır. Soğumaya başlayan yapraklar süzülerek ince ince bıçak yardımı ile doğranır. Yemek için ilk önce az miktarda yağ ile ince kıyılmış soğanlar kavrulur. Kavrulan soğanların üzerine kaşık ucuyla salça, tuz ve karabiber eklenir. Kavrulan bu karışımın üzerine 2 adet (isteğe bağlı) yumurta kırılır. Kırılan yumurta ile kavrulan soğan karışımı pişirilir. Pişen bu karışımın içine ince ince doğranmış ışgın yaprakları ilave edilir ve karıştırılır. Tamamen harmanlanan yemek ocaktan indirilir. İster soğuk bir şekilde, isterse sıcak bir şekilde yufka ekmeğin arasına dürüm yapılarak tüketime hazırlanır (Şekil 3).

Çizelge 3. Yemek yapımında kullanılan doğal bitkilere ilişkin bilgiler

\begin{tabular}{lc}
\hline Yemek yapımında kullanılan bitkilerin temin biçimleri & $\%$ \\
\hline Köy pazarlarından satın alıyorum & 86,4 \\
Doğadan topluyorum & 6,8 \\
Diğer & 6,8 \\
\hline Bitkilerin kullanılan kısımları & $\%$ \\
\hline Kök & 3,4 \\
Sürgün/yaprak & 96,6 \\
\hline Yöresel bitkilerin yemek yapımında kullanımı ile ilgili & $\%$ \\
bilgi kaynakları & \\
\hline Aile büyükleri & 98,3 \\
İnternet, TV vb. & 1,7 \\
\hline Yemek yapımında sıklık & $\%$ \\
\hline Yılda 1 defa & 35,6 \\
Ayda 1 defa & 55,9 \\
Haftada 1 defa & 8,5 \\
\hline
\end{tabular}
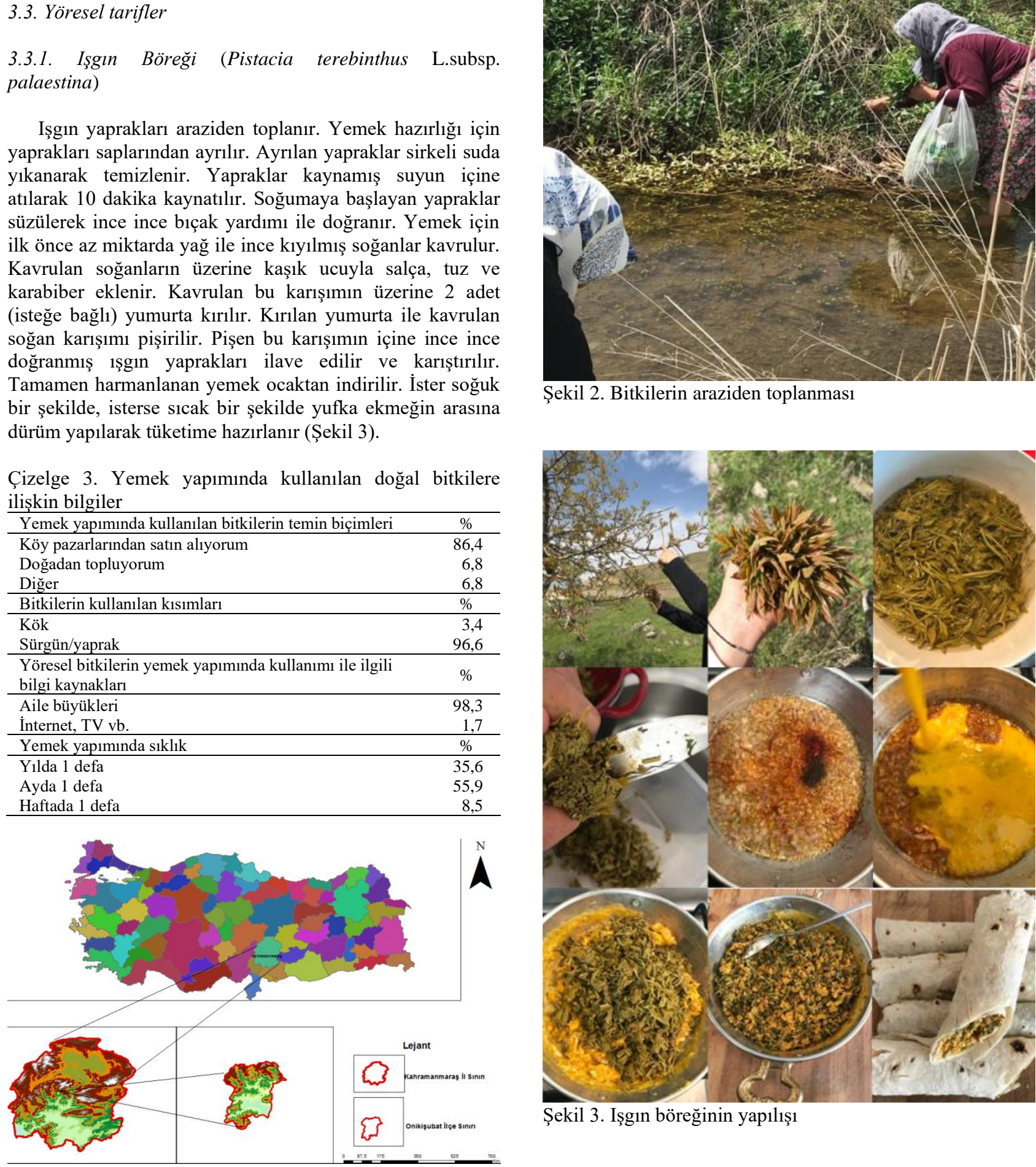

Şekil 2. Bitkilerin araziden toplanması

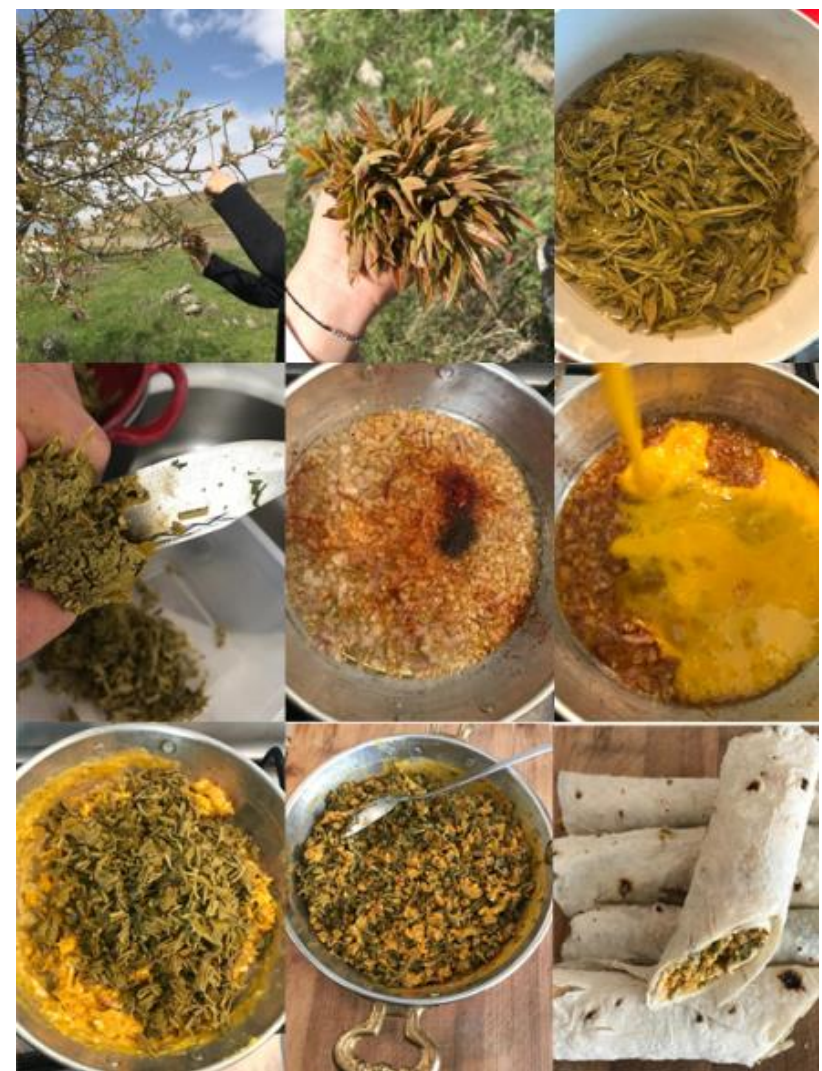

Şekil 3. Işgın böreğinin yapılışı

Şekil 1.Kahramanmaraş İli, Onikişubat İlçesi gösterir harita 


\subsubsection{Tirşik çorbası (Arum maculatum L.)}

Tırşik yaprakları araziden toplanır. Yemek hazırlığı için yaprakları saplarından ayrılır. Ayrılan yapraklar sirkeli suda yıkanarak temizlenir. Temizlenen tırşikler ince ince doğranır. Düdüklü tencereye sıcak su koyulur, içine doğradığımız tırşikler, un, yoğurt ve Maraş tarhanası koyulur ve karıştırılır, daha sonra düdüklü tencerenin ağzı kapatılır ve mayalanması için bir gece üstü bezlerle örtülerek iyice üstü kapatılır. Ertesi gün üstü açılır ve kısık ateşte en az bir saat kaynatılır ve son olarak haşlanmış nohutlar içine atılarak kısık ateşte 10 dakika daha kaynatılarak altı kapatılır ve tuzu atılarak servise hazırlanır (Şekil 4).

\subsubsection{Yarpuzlu ayran çorbası (Mentha pulegium L.)}

Yarpuz yaprakları araziden toplanır. Yemek hazırlığı için yaprakları saplarından ayrılır. Ayrılan yapraklar sirkeli suda yıkanarak temizlenir. Temizlenen yarpuz yaprakları ince ince doğranır. Bir gün önceden buğdaylar suda islatılır ve şişmesi beklenir. Şişen buğdayların üstü kapanacak şekilde sıcak su koyularak pişmesi sağlanır. Yumuşayan buğdayların içine tuz ve yarpuz ekleyerek bir güzel karıştırılır. Yarpuzun rengi değişip yumuşama olduğunda ocaktan indirilir ve soğumaya bırakılır. Soğuyan karışımın içine isteğe bağlı olarak sarımsaklı veya sarımsaksız süzme yoğurt eklenir. Eklenen yemek bir güzel harmanlanır ve sunuma hazırlanır (Şekil 5).

\subsubsection{Ebegümeci Lepesi (Malva sylvestris L.)}

Ebegümeci yaprakları araziden toplanır. Yemek hazırlığı için yaprakları saplarından ayrılır. Ayrılan yapraklar sirkeli suda yıkanarak temizlenir. Yapraklar küçük parçalar halinde doğranır. Yemek için ilk önce az miktarda yağ ile ince kıyılmış soğanlar kavrulur. Kavrulan soğanların üzerine kaşık ucuyla salça, tuz ve karabiber eklenir. Karıştırdıktan sonra 1 l1k su eklenip kaynaması beklenir. Kaynayan suyun içine göz kararı (isteğe bağlı) bulgur eklenir ve karıştırılır. Bulgur pişmeye yakın doğranmış ebegümeçleri üzerine ilave edilir. Ebegümeçleri ile bulgur karıştırılıp, kısık ateşte 10 dakika kaynatılır ve daha sonra ocaktan alınarak sunuma hazırlanır (Şekil 6).

\subsubsection{Gelinali böreği (Papaver rhoeas L. )}

Gelinali yaprakları araziden toplanır. Yemek hazırlığı için yaprakları saplarından ayrılır. Ayrılan yapraklar sirkeli suda yıkanarak temizlenir. Temizlenen Gelinali yaprakları ince ince doğranır. Doğranan Gelinali yaprakları tavada kuru soğan ve az yağ ile sotelenip, soğuduktan sonra isteğe bağlı olarak peynir ile birlikte bir karışım elde edilir. Hamuru için un, tuz ve su karışımı yumuşak bir hamur hazırlanır, hazırlanan hamur bir saat dinlendikten sonra küçük küçük bezelere bölünür. Bezeler yuvarlak bir şekilde hazırlanır ve içine yapmış olduğumuz malzemeler koyulur. Ay şeklinde bir ucundan malzemeli olan yerin üstüne kapatılır. Hazırlanan börekler tavada arkalı önlü pişirilip tereyağı ile yağlanır ve servise hazırlanır (Şekil 7).

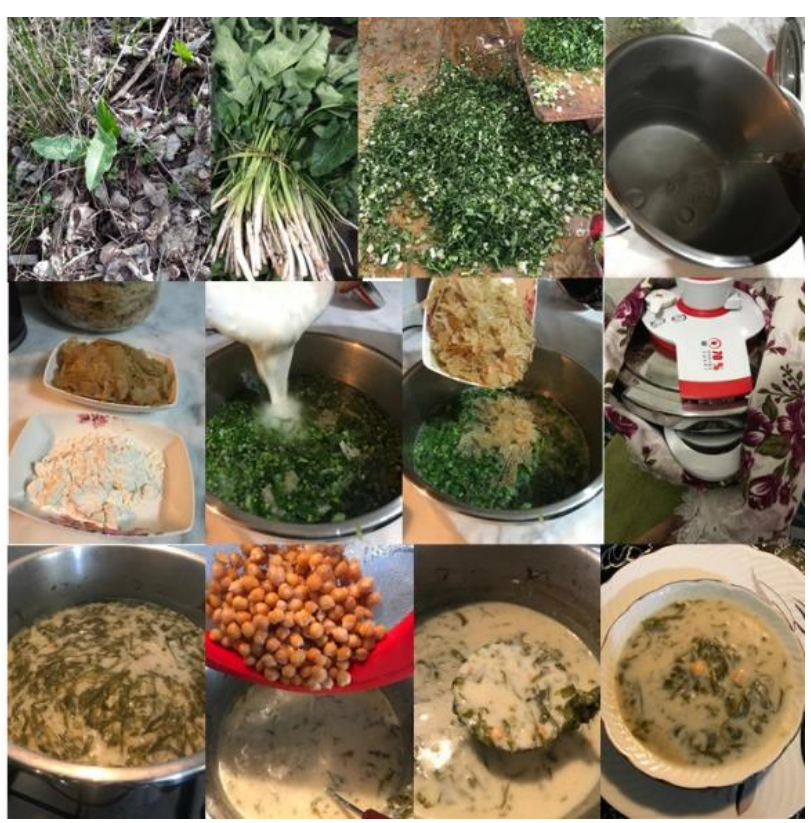

Şekil 4. Tırşik çorbasının yapılışı

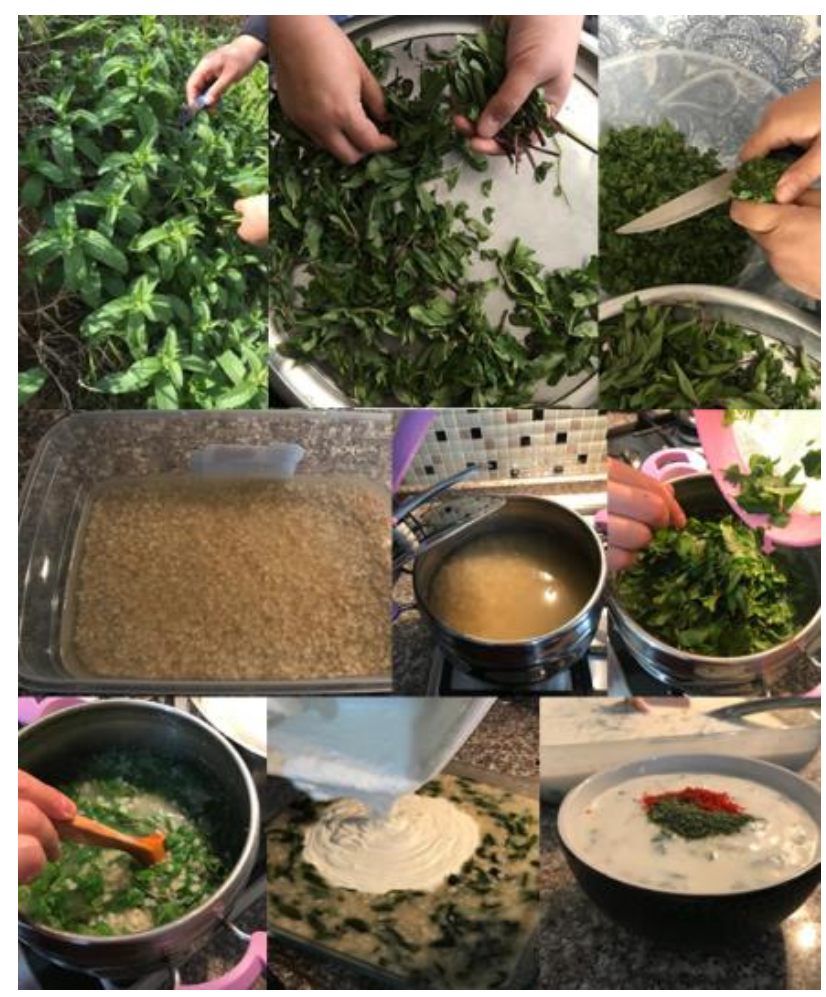

Şekil 5.Yarpuzlu ayran çorbasının yapılışı 


\subsubsection{Semizotu ekşili çorba (Portulaca olerace L.)}

Semizotu yaprakları araziden toplanır. Yemek hazırlığı için yaprakları saplarından ayrılır. Ayrılan yapraklar sirkeli suda yıkanarak temizlenir. Temizlenen semizotu ince ince doğranır. Bir su bardağı kırmızı mercimek ile bir su bardağ buğday düdüklü tencereye koyulup bir miktar su ilave edilerek pişmesi için ocağa koyulur. Pişen karışımın içine doğranmış olan semizotları ile birlikte yöresel sumak ekşisi de koyularak karıştırılır. İki-üç diş sarımsak havanda ezilir, az miktarda yağ ile kavrulur ve içine karabiber, kırmızıbiber ve tuz atıldıktan sonra bir güzelce kavrulur ve bu karışım tencerenin üzerine ilave edilir. Hepsi karıştırıldıktan sonra servise hazırlanır (Şekil 8).

\subsubsection{Yumurtall ispatan salatass (Nasturtium officinale R.Br.)}

Ispatan yaprakları araziden toplanır. Yemek hazırlığı için yaprakları saplarından ayrılır. Ayrılan yapraklar sirkeli suda yıkanarak temizlenir. Temizlenen ispatan yaprakları, yeşil soğan, biber ve yumurta ince ince kiyılır. Kıyılan malzemeler zeytinyağı, tuz, limon, kırmızı toz biber karıştırılarak servise hazırlanır (Şekil 9).

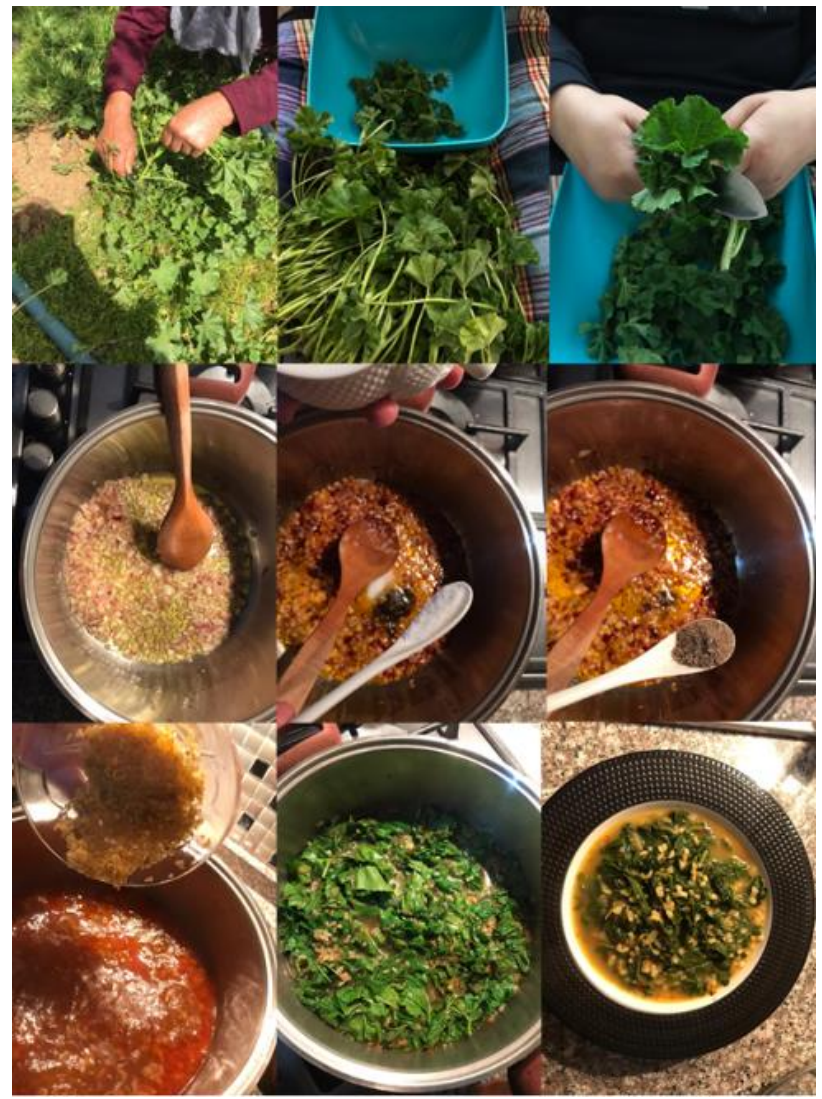

Şekil 6. Ebegümeci lepesinin yapılışı

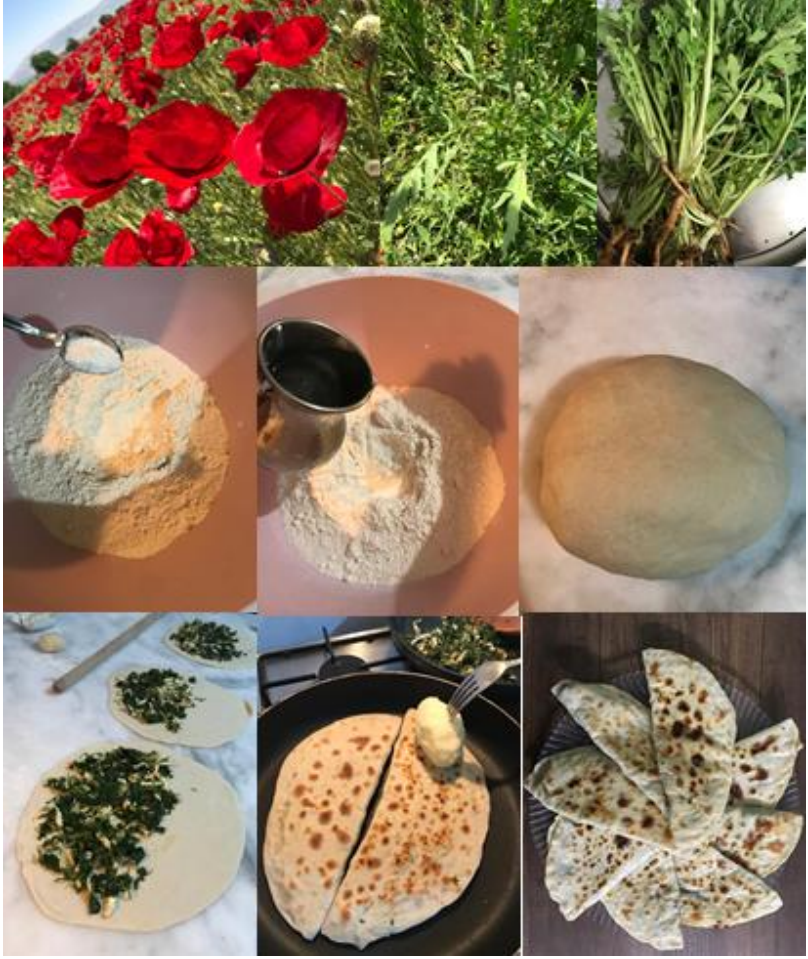

Şekil 7. Gelinali böreğinin yapılışı

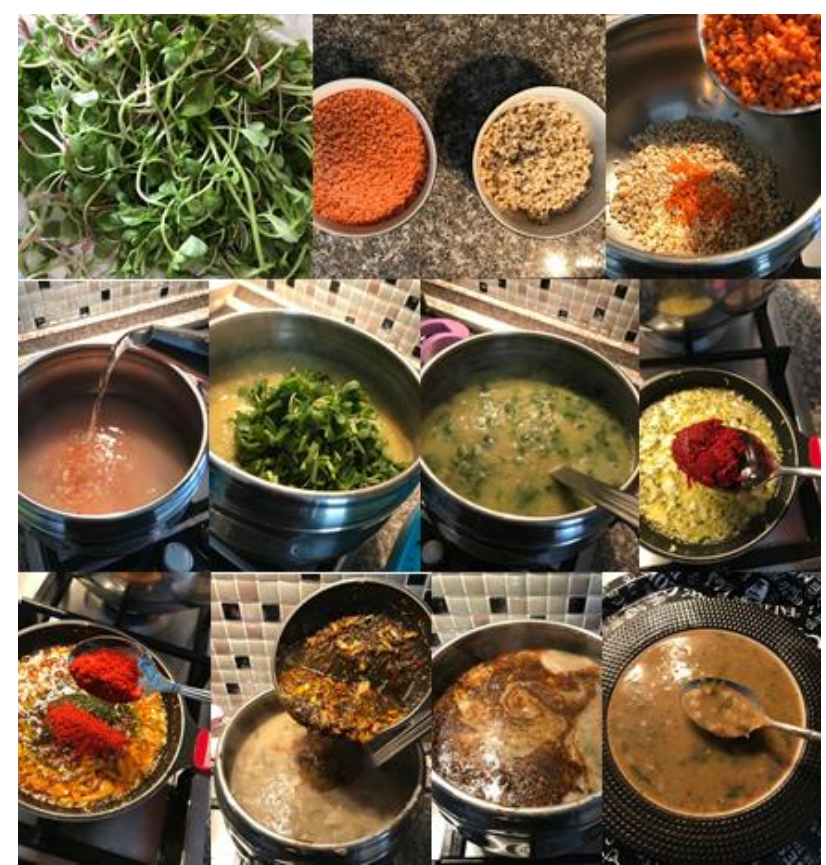

Şekil 8. Semizotu ekşili çorba yapılışı 


\subsubsection{Istrgan lepesi (Urtica dioica L.)}

Isırgan yaprakları araziden toplanır. Yemek hazırlığı için yaprakları saplarından ayrılır. Ayrılan yapraklar sirkeli suda yıkanarak temizlenir. Temizlenen 1sirganlar ince ince doğranır. Bir tane soğan ince ince doğranıp az miktarda yağ ile kavrulur ve içine karabiber, kırmızıbiber ve tuz atıldıktan sonra doğranan 1sırganlar içine atılır. Bütün malzemeler karıştırılarak kavrulur. Hazırlanan karışımın içine su ilave edilir ve kaynamaya bırakılır. Kaynayan sulu karışımın içine bulgur ve doğranmış ısırgan otları ilave edilerek pişmeye bırakılır. Suyu çeken yemeğin altı kapatılarak dinlenmeye alınır ve servis edilir (Şekil 10).

\subsection{9. Çiriş böreği (Asphodelus aestivus Brot.)}

Çiriş yaprakları araziden toplanır. Yemek hazırlığı için yaprakları saplarından ayrılır. Ayrılan yapraklar sirkeli suda yıkanarak temizlenir. Temizlenen çiriş yaprakları ince ince doğranır. Doğranan çirişler sıcak suyun içine atılır ve yumuşayınca süzülür. Bir tane soğan ince ince doğranıp az miktarda yağ ile kavrulur ve içine karabiber, kırmızıbiber ve tuz atıldıktan sonra yumuşayan çirişler içine atılır. Bütün malzemeler bir güzelce karıştırılarak kavrulur. Soğuması için ocaktan alınır. Hamuru için un, tuz ve su eklenerek yumuşak bir hamur hazırlanır, hazırlanan hamur 1 saat dinlendikten sonra küçük küçük bezelere bölünür. Bezeler isteğe bağlı olacak şekilde yuvarlak bir şekilde hazırlanır ve içine yapmış olduğumuz malzemeler koyulur. Ay şeklinde bir ucundan malzemeli olan yerin üstüne kapatılır. Hazırlanan börekler kızgın yağda bir güzelce arkalı önlü kızartılır. İsteğe bağlı olarak ister sıcak isterse soğuk olarak servis edilir (Şekil 11).

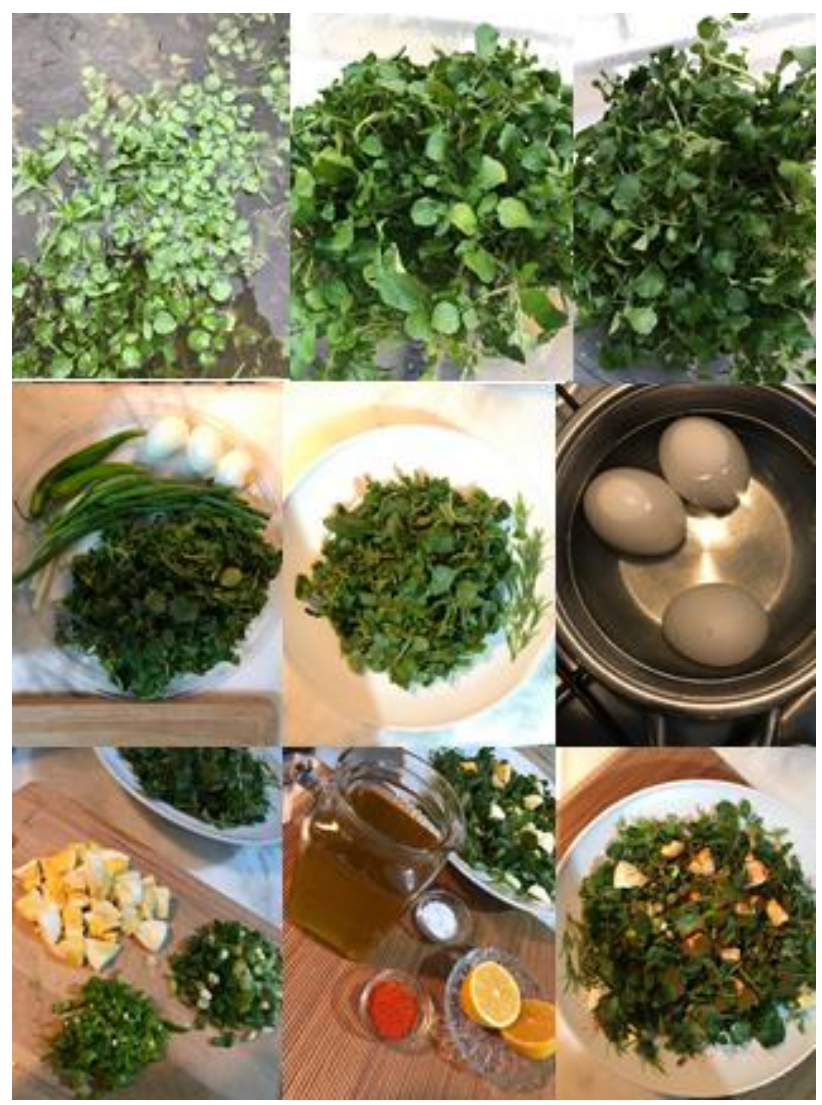

Şekil 9. Yumurtalı Ispatan salatası yapılışı

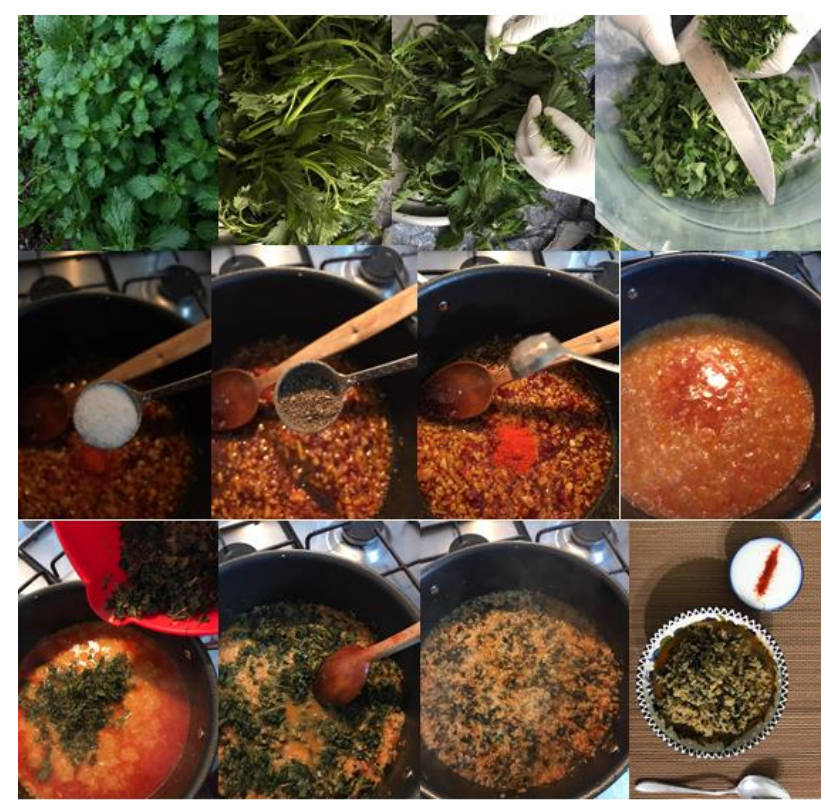

Şekil 10. Isırgan lepesi çorbasının yapılışı

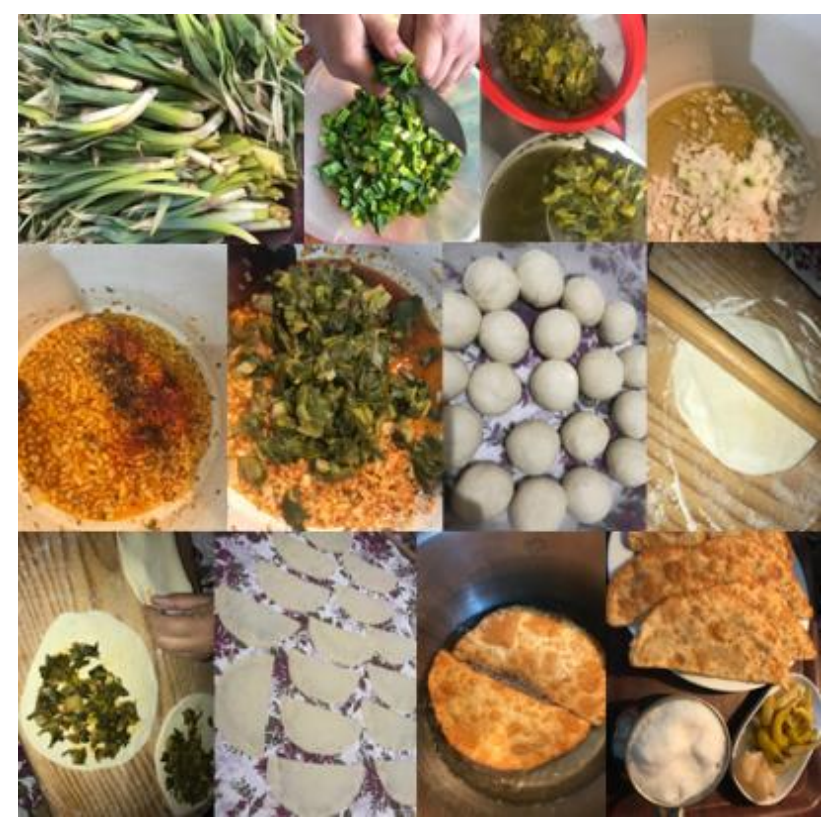

Şekil 11. Çiriş böreğinin yapılışı 


\section{Tartışma ve sonuç}

Yapılan bu araştırma ile Onikişubat (Kahramanmaraş) yöresinde gıda olarak tüketilen doğal bazı bitki taksonlarına ait yöresel tarifler hakkında bir veri tabanı oluşturulmuştur. Anket çalışmaları sonucunda elde edilen bilgiler ışı̆̆ında yemek yapımında kullanılan doğal bitkilerin temin biçimleri, kullanılan kısımları ve kullanıma ilişkin bilgi kaynakları literatürde yapılan çalışmalarla (Korkmaz ve Dündar, 2019; Korkmaz vd., 2011; Fakir vd., 2009; Korkmaz ve Fakir, 2009) benzerlik göstermektedir.

Yapılan arazi çalışmaları sonucu yörede, yemek yapımında en fazla kullanılan bitkiler; ışgın ( $P$. terebinthus subsp. palaestina), tırşik (A. maculatum), yarpuz ( $M$. pulegium), ebegümeci (M. sylvestris), gelinali ( $P$. rhoeas), semizotu ( $P$. oleracea), su teresi, ispatan ( $N$. officinale), 1sırgan (U. dioica), çiriş (A. aestivus)'dir.

Samavati ve Manoochehrizade (2013)'nin çalışmalarında Malva sylvestris' in taze yaprakları çiğ olarak ve yaprak ile sürgünlerini çorbalarda kullanıldığını belirtmiştir. Sargın (2019)'nın çalışmasında yapraklar kurutulup çay olarak tüketildiği, taze yaprakların haşlanıp soğan ve biberle kavrularak yendiği, üzerine yumurta kırılarak tüketildiği belirtilmiştir. Hakverdi ve Yiğit (2017)'in yapmış olduğu çalışmalarında ebegümeci yapraklarının kurutulup çay olarak tüketildiğini bildirmişlerdir. İnaltong (2015)'un çalışmasında ise ebegümeci büyük yapraklarından sarma yapımında ve börek için iç malzeme yapımında, taze yaprakları ise haşlanarak yoğurtlu mezesi ve pirinçli yemeğinin yapıldığını bildirmiştir. Çalışmamız yukarıda bahsedilen çalışmalarla bazı benzerlikler göstermiş olsa da, küçük farklıklar bulunmaktadır.

Tunçgenç ve Tunçgenç (2008), yapmış olduğu çalışmalarında Papaver rhoeas'ın taç yaprakları suda kaynatıldıktan sonra içerisine limon ve şeker katılarak yoğunlaştırıp şerbet olarak tüketildiği bildirmişlerdir. Tuzlacı (2011)'nın yapmış olduğu çalışmasında, yaprakları börek, salata, köfte yapımında ve yaprakları kavrularak tüketildiğini bildirmiştir ve bu çalışma ile çalışmamızın benzerlik gösterdiği belirlenmiştir.

Asphodelus aestivus 'nun yapraklarının gulik çorbası yapımında kullanıldığı ve yine aynı çorbaya süt ilave edilerek te tüketildiği belirtilmiştir (TV, 2020; Terzioğlu, 2020). Aynı zamanda bitki yapraklarının kavrularak tüketildiği de bildirilmiştir (YG, 2020). Alpaslan ve Önal (2016)'ın yapmış olduğu çalışmalarında, çiriş bitkisinden hem bulgur pilavı hem de çiriş ketesi yapımının olduğu ve yaptı̆̆ımız çalışma ile benzerlik gösterdiği tespit edilmiştir.

Sargın (2019)'nın yapmış olduğu çalışmada, $P$. terebinthus subsp. terebinthus yapraklarının kurutulup çay olarak ve tohumlarının yaş olarak veya kavrularak çerez gibi tüketildiği belirtilmiştir. Tugay vd. (2012)'nin yapmış olduğu çalışmalarında, genç dönemlerde sürgünlerinin yenildiği, tohumlarının çerez olarak tüketildiği ve tohumlarının ögütülerek kahvelerin içine koyulduğunu belirtmişlerdir. Akyol (2020) ve Hakverdi (2020)'nin yenilebilir yabani otlardan olan bu ürünlerin yerel halk için önemli doğal kaynak olduğu ve bu kaynaklardan maksimum fayda sağlayarak ekonomik anlamda bölge halkının kalkınacağını bildirmişlerdir. Çalışmamız, ışgın (menengiç) yapraklarının kavrularak tüketilmesi ile farklılık göstermektedir.
Aksoy vd. (2016)'un yapmış olduğu çalışmada, $M$. pulegium taze yapraklarının ayran çorbasında baharat olarak kullanıldığını bildirmişlerdir. Güneydoğu Anadolu'da yarpuzun, ekşimsi bir tadı olduğu ve taze yapraklarının salata, köfte ve piyaz yapımında kullanıldığı belirtilmiştir (Gürsoy ve Gürsoy, 2020). Yarpuz çorba yapımı diğer çalışmalardan farklı olarak bol miktarda yarpuz yeşil iken doğranır ve bulgur ile soğuk bir çorba hazırlanır.

Karaevli ve Sarıkaya (2019)'nın yapmış olduğu çalışmalarında, toplanan nünük (Arum spp.) bitkisinin mısır unu ile kavrularak tüketildiğini bildirmişlerdir. Çalışmamızda ise yöresel tarhana ile yapılan çorba farklılık göstermektedir.

Ceylan ve Yücel (2015)'in yapmış olduğu çalışmalarında, taze 1sırgan (U. dioica) otunun çorba yapımında kullanıldığı belirtilmiştir. Facciola ve Cornucopia (1990)'nın yapmış olduğu çalışmalarında ise, taze 1sırganotu yapraklarının çorba ve çay olarak tüketiminin yaygın olduğu bildirilmiş ve ısırgan otunun ayrica otlu omlet, otlu tavuk köftesi, püre, otlu lahmacun, gözleme ve börek olarak tüketildiği de bildirmişlerdir. Çalışmamızda ısırganotu bulgur ile bir yemek yapılmış olup yapılan diğer çalışmalar ile farklılık göstermektedir.

Yücel vd. (2012)'nin yapmış olduğu çalışmalarında, $P$. oleracea yapraklarından sulu yemek yapımının olduğu ve aynı zamanda börekler için iç harç olarak kullanıldığını belirtmişlerdir. Altay ve Karahan (2012)'nın yapmış olduğu çalışmalarında ise taze yaprakları yoğurtla cacık yapılarak tüketildiğini söylemişlerdir. Çalışmamızda yöresel sumak ekşisi ile yapılan bir çorba elde edilmiş olup yapılan çalışmamalarla farklılık göstermektedir.

İnaltong (2015)'un yapmış olduğu çalışmasında, $N$. officinale bitkisinin salatalarda, çorbalarda, börek içinde kullanıldığını bildirmiştir. Polat vd. (2012)'nin çalışmalarında ise, salatalarda ve haşlanıp yemek olarak tüketildiği bildirilmiştir. Çalışmamız da salata olarak tüketilmekte olup diğer çalışmalar ile tarif açısından benzerlikler göstermektedir.

Doğal otların tüketimi gün geçtikçe artmakta olup, yapılan yöresel yemekleri pişirme ve tüketme şekilleri farklılık göstermesi Anadolu'nun kültürel anlamda zenginliğini ortaya koymuştur. $\mathrm{Bu}$ doğal yetişen bitki türlerimizin sürekliliği ve korunması son derece önemlidir. $\mathrm{Bu}$ yüzden yapılan bu çalışmanın gastronomi turizmine, gıda ve tarım sektörlerinde de ekonomik anlamda katkı sağlayacağı düşünülmektedir.

\section{Açıklama}

Yazar Ebru Hatice Tığlı Kaytanlığlu sürdürülebilir ormancılık tematik alanında 100/2000 YÖK doktora öğrencisidir.

\section{Kaynaklar}

Aksoy, A., Çelik, J., Tunay, H., 2016. Gazipaşa (Antalya) ilçe pazarında satılan ve halk tarafindan kullanılan bazı bitkiler ve kullanım amaçları. Research Journal of Biology Sciences, 9(2): 55-60.

Akyol, A., 2020. Burdur-Gölhisar Yöresinde Odun Dış1 Orman Ürünlerinin ve Çıntar Mantarının Yerel Halk Açısından Önemi. Ziraat, Orman ve Su Ürünleri Alanında Teori ve Araştırmalar II. Gece Kitaplı̆̆ 1 , Ankara.

Alpaslan, İ., Önal, Ö., 2016. Ağrı bölgesi karapapak terekemelerin yaptığ 1 yemekler. Uluslararası Karadeniz Havzası Halk Bilimi Araştırmaları Dergisi, 1(6): 98-123. 
Altay, V., Karahan, F., 2012. Tayfur Sökmen Kampüsü (AntakyaHatay) ve çevresinde bulunan bitkiler üzerine etnobotanik bir araştırma. Karadeniz Fen Bilimleri Dergisi, 3(2): 13-28.

Baş, T., 2010. Anket. Seçkin Yayıncılık, Ankara.

Ceylan, F., Yücel, E., 2015. Düzce ve çevresinde gida olarak tüketilen yabani bitkilerin tüketim biçimleri ve besin öğesi değerleri. Afyon Kocatepe University Journal of Science \& Engineering, (15): 1-17.

Davis, P.H., 1985. Flora of Turkey and East Aegean Islands, Vol 2. University Pres, Edinburgh.

Facciola, S., Cornucopia, A., 1990. Source Book of Edible Plants. Kampong Publications, Vista.

Fakir, H., Korkmaz, M., Güller, B., 2009. Medicinal plant diversity of western Mediterrenean region in Turkey. Journal of Applied Biological Sciences, 3(2): 30-40.

Gürsoy, H., Gürsoy, M.E.,, 2020. Güneydoğu Anadolu'nun mis kokulu otu: Yarpuz. https://www.bilgiustam.com, Erişim: 12.01.2020.

Hakverdi, A.E., Yiğit, N., 2017. Yozgat-Akdağmadeni yöresinde bulunan bazı tıbbi ve aromatik bitkiler. Bartın Orman Fakültesi Dergisi, 19(2), 82-87.

Hakverdi, A.E., 2020. Isparta Uygulamalı Bilimler Üniversitesi Orman Mühendisliği Bölümü öğrencilerinin tarımsal ormancılık kavramı ve uygulamaları hakkında bilgi düzeyleri. Turkish Journal of Forest Science, 4(1): 60-71.

İnaltong, T., 2015. Türkiye'nin otları. http://www. turkishcuisine.org./, Erișim: 12.01.2020.

Kallas, J., 1996. Edible wild plants from neighborhood to wilderness: A catalyst for experiential education. 1996 Association for Experiential Education 24th Annual International Conference Proceedings, September 26-29, Spokane, WA, pp. 140-144.

Karaca, O.B., Yıldırım, O., Çakı1c1, C., 2015. Gastronomi turizminde otlar, ot yemekleri ve sağllkla ilişkisi üzerine bir değerlendirme. Journal of Tourism and Gastronomy Studies, 3(3): 27-42.

Karaevli, A., Sarıkaya, A.G., 2019. Korgan (Ordu) yöresinde doğal yayılıș gösteren bitki taksonlarının etnobotanik özellikleri. Journal of Tourism and Gastronomy Studies, 7(2): 1108-1123.

KTB, 2020. Kahramanmaraş il kültür ve turizm müdürlüğü. https://kahramanmaras.ktb.gov.tr/, Erișim: 12.11.2020.

Knight, J.A., 2000. The biochemistry of aging. Advances in Clinical Chemistry, 35: 1-62.
Korkmaz, M., Dündar, N., 2019. Tüketicilerin odun dıșı orman ürünlerine yönelik satın alma tercihlerini etkileyen faktörler. Turkish Journal of Forestry, 20(3): 213-220.

Korkmaz, M., Fakir, H., 2009. Odun dışı bitkisel orman ürünlerine ilişkin nihai tüketici özelliklerinin belirlenmesi (Isparta iline yönelik bir araştırma). SDÜ Orman Fakültesi Dergisi, A(1): 10-20.

Korkmaz, M., Fakir, H., Guller, B., 2011. Consumer preferences for medicinal and aromatic plant products: Surveys of urban consumers and sellers in western mediterranean region of Turkey. Journal of Medicinal Plants Research (ISI), 5(10): 2054-2063.

Polat, R., Selvi, S., Çakılcığlu, U., Açar, M., 2012. Investigations of ethnobotanical aspect of wild plants sold in Bingöl (Turkey) local markets. Journal of Biological Diversity and Conservation, 5(3): 155-161.

Samavati, V., Manoochehrizade, A., 2013. Polysaccharide extraction from Malva sylvestris and its anti-oxidant activity. International Journal of Biological Macromolecules, 60: 427-436.

Sargın, S., 2019. Mersin'in Bozyazı ilçesinde gıda olarak tüketilen yabani bitkiler. Yüzüncü Y1l Üniversitesi Fen Bilimleri Enstitüsü Dergisi, 24(3): 152-169.

Terzioğlu, S.,, 2020. Çiriş çorbası. http://www.tuzekmek.com/ciris-otu-corbasi, Erişim: 12.01.2020.

Tugay, O., Bağcı, İ., Ulukuş, D., Özer, E., Canbulat, M.A., 2012. Kurucuova Beyşehir, Konya/Türkiye Kasabası'nda gıda olarak kullanılan doğal bitkiler. Biyolojik Çeşitlilik ve Koruma, 5(3): 140-145.

Tunçgenç, Ş., Tunçgenç, M., 2008. Giritli Türklerin Mutfağından Ot ve Sebze Yemekleri. Türkiye İş Bankası Kültür Yayınları, İstanbul.

Tuzlacı, E., 2011. Türkiye'nin Yabani Besin Bitkileri ve Ot Yemekleri. Melisa Matbaacılık. İstanbul.

TV, 2020. T.C. Tunceli Valiliği. Bir tutam Tunceli. www.tunceli.gov.tr, Erişim: 12.01.2020.

YG, 2020. Yenişafak Gazetesi. Maraş mutfağının saklı lezzetleri. https://www.yenisafak.com/, Erişim: 12.11.2020.

Yücel, E., Şengün, İ.Y., Çoban, Z., 2012. Afyonkarahisar çevresinde gida olarak tüketilen yabani otlar ve tüketim biçimleri. Biyolojik Çeşitlilik ve Koruma, 5(2): 95-105. 